\title{
Analisis Faktor Resiko Kejadian Infertilitas Pada Perawat di RSU Sembiring
}

\author{
Ribka Flora Panjaitan ${ }^{(1)}$, Evalina Manurung ${ }^{(2)}$ \\ Institut Kesehatan Deli Husada Deli Tua \\ Corresponding author : ribka.florapanjaitan@gmail.com
}

Ribka.florapanjaitan@gmail.com (1), evalinamanurung85@gmail.com (2)

\begin{abstract}
ABSTRAK
Latar Belakang: Infertilitas atau Infekunditas merupakan suatu penyakit pada sistem reproduksi yang dapat didefinisikan sebagai kegagalan untuk mencapai kehamilan klinis setelah 12 bulan atau lebih berhubungan seksual tanpa penggunaan alat kontrasepsi. Infertilitas pada pasangan usia subur di seluruh dunia diperkirakan sekitar 50-80 juta. Di Indonesia, 10-15\% jumlah penduduk mengalami infertilitas. Prevalensi wanita usia subur yang mengalami infertilitas diperkirakan mencapai 6,08\%. Prevalensi infertilitas tertinggi terdapat pada usia 20-24 tahun sebanyak 21,3\%. Sedangkan prevalensi infertilitas terendah pada usia 40-44 tahun yaitu 3,3\%. Penelitian ini bertujuan untuk menganalisis faktor resiko kejadian Infertilitas pada Perawat di RSU. Sembiring dengan variabel penelitian (Umur, Masa Kerja, Status Gizi, Infeksi Organ Reproduksi dan Paparan rokok). Rancangan penelitian yang akan digunakan adalah crossectional study dengan pendekatan retrospektif. Pengumpulan data akan dilakukan melalui wawancara yang berpedoman pada kuesioner yang telah memenuhi unsur validitas dan reliabilitas dan pengukuran Body Mass Index (BMI). Sampel dalam penelitian ini berjumlah 70 orang Perawat di RSU. Sembiring, Delitua, Deli Serdang. Analisis data secara univariat, bivariat dan multivariate. Hasil aanalisis statistik pada tahapan Multivariat menunjukkan bahwa terdapat 3 variabel yang berhubungan dengan kejadian Infertilitas pada perawat di RSU. Sembiring yaitu Masa Kerja dengan nilai sig.0,006, Status Gizi dengan nilai sig.0,029 dan Infeksi pada Organ Reproduksi dengan nilai sig. 0,003.
\end{abstract}

Kata Kunci : Infertilitas, Perawat, Kesehatan Kerja

\begin{abstract}
Background: Infertility or infecundity is a disease of the reproductive system which can be defined as a failure to achieve clinical pregnancy after 12 months or more of sexual intercourse without the use of contraceptives. Infertility among reproductive age couples worldwide is estimated at around 50-80 million. In Indonesia, 10$15 \%$ of the population is infertile. The prevalence of women of childbearing age experiencing infertility is estimated at $6.08 \%$. The highest prevalence of infertility was found at the age of 20-24 years as much as $21.3 \%$. Meanwhile, the lowest prevalence of infertility was at the age of 40-44 years, namely $3.3 \%$. This study aims to analyze the risk factors for the incidence of infertility among nurses at the hospital. Along with research variables (Age, Working Period, Nutritional Status, Reproductive Organ Infections and Cigarette Exposure). The research design that will be used is a cross-sectional study with a retrospective approach. Data collection will be carried out through interviews guided by questionnaires that have met the elements of validity and reliability and measurement of the Body Mass Index (BMI). The sample in this study amounted to 70 nurses at the hospital. Sembiring, Delitua, Deli Serdang. Data analysis was univariate, bivariate and multivariate. The results of statistical analysis at the multivariate stage showed that there were 3 variables related to the incidence of infertility in nurses at the hospital. Sembiring, namely the working period with a sig. 0.006 value, nutritional status with a sig.0.029 value and infection in the reproductive organs with a sig value. 0.003 .
\end{abstract}

Keywords : Infertility, Nurse, Occupational Health 
Flora Panjaitan R, Manurung E: Analisis Faktor Resiko Kejadian Infertilitas Pada Perawat di RSU Sembiring

\section{PENDAHULUAN}

\section{Latar Belakang}

Infertilitas merupakan suatu krisis dalam kehidupan yang akan berpengaruh kepada berbagai aspek kehidupan seseorang. Sangat manusiawi dan normal bila pasangan infertilitas mempunyai perasaan yang berpengaruh kepada kepercayaan diri dan citra diri. Lebih parah lagi menurut The National Infertility Association menyebutkan beberapa gejala yang dapat terjadi antara lain, timbul perasaan sedih, depresi atau putus asa. Memiliki anak penting bagi semua masyarakat di dunia dan perkawinan merupakan salah satu sarana untuk mendapat keturunan. Pada beberapa pasangan, impian untuk memiliki keturunan bukanlah sesuatu yang mudah untuk diwujudkan. Memiliki anak yang baik dapat merupakan kebanggan tersendiri dan secara ekonomi juga dianggap menguntungkan sebagai investasi di masa tua. Anak mempunyai peranan sosial yang cukup penting, keberadaan anak menyebabkan ikatan keluarga menjadi kokoh tidak mudah goyah, anak merupakan sumber motivasi keluarga menata masa depan lebih baik. Prevalensi infertilitas yang tepat tidak diketahui dengan pasti, sangat bervariasi tergantung keadaan geografis, budaya dan status sosial negara tersebut. ${ }^{7}$ Kebiasaan masyarakat timur yang membicarakan atau menganggap segala sesuatu yang berhubungan dengan seks itu tabu dan privasi sehingga tidak layak untuk dibicarakan memberi kontribusi terhadap kejadian infertilitas. Semakin banyaknya wanita karir yang menikah pada usia lebih dewasa pada status sosial yang lebih tinggi akan sangat mempengaruhi kesuburan seorang wanita. Sedangkan data infertilitas di seluruh dunia menurut Badan Kesehatan Dunia (World Health Organization, WHO) dan laporan lainnya, diperkirakan 8-12\% pasangan yang mengalami masalah infertilitas selama masa reproduktif mereka. Jika delapan persen dari gambaran global populasi maka sekitar 60-80 juta pasangan yang belum dikarunia anak. Diperkirakan muncul sekitar 2 juta pasangan infertil baru setiap tahun dan jumlah ini terus meningkat. Angka infertilitas di Indonesia yang dikemukan oleh Sumapraja berkisar $(12-15 \%){ }^{6}$ Banyaknya pasangan infertilitas di Indonesia dapat di perhitungkan dari banyaknya wanita yang pernah kawin dan tidak mempunyai anak yang masih hidup. Menurut sensus penduduk terdapat (12\%) baik di desa maupun di kota atau sekitar 3 juta pasangan infertil tersebar di seluruh Indonesia, dari Jumlah tersebut terdapat perempuan infertil $15 \%$ pada Usia $30-34,30 \%$ pada usia $35-39$, dan $64 \%$ pada usia $40-44$ tahun. Berdasarkan jenis infertilitas dari 215 pasangan yang infertil terdapat 172 kasus (80 $\%$ ) pasangan yang mengalami infertilitas primer dan 43 kasus( $20 \%$ ) pasangan yang mengalami infertilitas sekunder. Dari semua wanita yang mengalami infertilitas di Amerika Serikat, infertilitas primer terdapat $65 \%$ wanita dan infertilitas sekunder terdapat $35 \%$ wanita. Secara global dapat disimpulkan penyebab terjadinya infertilitas diakibatkan dari faktor laki-laki sekitar 30\% meliputi kelainan pengeluaran sperma, penyempitan saluran mani karena infeksi bawaan, faktor immunologik/antibodi, antisperma, serta faktor gizi dan gangguan dari perempuan $30 \%$ yang mempunyai masalah pada vagina, serviks, uterus, kelainan pada tuba, ovarium dan pada peritoneum. gangguan dari keduanya $30 \%$ dan yang tidak di ketahui sekitar $10 \%$. Penyebab seorang wanita dan pria menjadi infertil juga dapat disebabkan oleh faktor risiko yang meningkat yaitu gaya hidup yang tidak terkontrol yang diterapkan sejak usia remaja. Faktor-faktor tersebut adalah usia, kebiasaan merokok, mengkonsumsi alkohol, stress, diet yang buruk, olah raga berat, mengalami overweight ataupun underweight, penyakit menular seksual, keadaan lingkungan yang buruk (polusi udara dan air), juga masalah kesehatan yang berhubungan dengan perubahan hormon.

\section{Perumusan Masalah}

Sebagaimana yang telah dijelaskan diatas bahwa faktor-faktor yang menyebabkan terjadinya infertiltas berbeda di setiap negara dan daerah, karena tergantung letak geografis, sosial budaya, ekonomi dan gaya hidup. Dengan megetahui data-data ini diharapkan pencegahan, 
Flora Panjaitan R, Manurung E: Analisis Faktor Resiko Kejadian Infertilitas Pada Perawat di RSU Sembiring

penanganan dan pelayanan bagi kasus-kasus infertilitas lebih dapat ditingkatkan dan dapat ditangani lebih komprehensip sehingga penderitaan wanita yang mengalami infertilitas dapat dikurangi.

\section{Tujuan Penelitian}

Penelitian ini bertujuan yaitu :

1. Untuk menganalisis hubungan faktor umur dengan kejadian Infertilitas pada Perawat di RS Sembiring.

2. Untuk menganalisis hubungan faktor Masa Kerja dengan kejadian Infertilitas pada Perawat di RS Sembiring.

3. Untuk menganalisis hubungan faktor Status Gizi dengan kejadian Infertilitas pada Perawat di RS Sembiring.

4. Untuk menganalisis hubungan faktor Infeksi Organ Reproduksi dengan kejadian Infertilitas pada Perawat di RS Sembiring.

5. Untuk menganalisis hubungan faktor Paparan rokok dengan kejadian Infertilitas pada Perawat di RS Sembiring.

\section{Manfaat Penelitian}

Bermanfaat sebagai sumber informasi mengenai bahwa wanita menyadari sejak usia muda pentingnya menjaga kesehatan reproduksi untuk mencegah timbulnya kasus wanita infertil. Skema penelitian ini adalah penelitian dasar secara retrospektif variabel-variabel penelitian yang sejalan dengan roadmap Kesehatan Reproduksi.

\section{METODE PENELITIAN \\ Rancangan Penelitian \\ Jenis Penelitian}

Jenis penelitian ini adalah penelitian analitik dengan desain crossectional yang bertujuan untuk menganalisis faktor - faktor yang berhubungan dengan kejadian Infertilitas pada Perawat di RSU Sembiring.

\section{Lokasi Penelitian}

Penelitian ini dilakukan di Kecamatan Biru-biru dengan pertimbangan bahwa di Penelitian ini dilakukan di RSU Sembiring, Delitua, Deli Serdang. Pemilihan lokasi penelitian didasarkan pada pertimbangan bahwa kejadian Infertilitas lebih sering dijumpai pada pekerja dengan ritme kerja yang melawan irama sirkardian tubuh yaitu pekerja dengan pola kerja shift malam.

\section{Populasi dan Sampel}

Populasi dalam penelitian ini adalah seluruh Perawat yang bekerja di RSU. Sembiring, Deltua, Deli Serdang.

Pemilihan sampel dalam penelitian ini menggunakan kriteria sebagai berikut:

1. Kriteria Inklusi

a) Perawat wanita dengan 3 shift kerja

b) Perawat wanita berusia $\leq 34$ tahun, sudah menikah selama 12 bulan atau lebih tetapi belum pernah hamil

c) Perawat wanita berusia $>35$ tahun, sudah menikah selama 6 bulan atau lebih tetai belum pernah hamil

d) Sudah bekerja selama \pm 1 tahun.

2. Kriteria Eksklusi

a) Tidak bersedia berpartisipasi dalam penelitian

b) Tidak berada di tempat sampai dengan kunjungan ketiga penelitian 
Flora Panjaitan R, Manurung E: Analisis Faktor Resiko Kejadian Infertilitas Pada Perawat di RSU Sembiring

Dalam penelitian ini penentuan sampel penelitian yaitu dengan menggunakan persamaan rumus slovin, sebagai berikut:

$$
n=\frac{N}{1+N e^{2}}
$$

Dengan ketentuan: $\quad \mathrm{n}=$ besar sampel

$$
\begin{gathered}
\mathrm{N}=\text { besar populasi } \\
\mathrm{e}=\text { perkiraan tingkat kesalahan } \\
\text { Maka, } n=\frac{225}{1+(225.0,001)}
\end{gathered}
$$

$$
\begin{aligned}
& \mathrm{n} \frac{225}{3,25} \\
& \mathrm{n}=69,2=70
\end{aligned}
$$

Sampel dalam penelitian ini berjumlah 70 orang Perawat di RSU. Sembiring, Delitua, Deli Serdang. Metode penarikan sampel yang digunakan adalah consecutive sampling, dimana semua perawat yang sesuai dengan kriteria dimasukkan sebagai responden sampai jumlah subjek yang diperlukan terpenuhi.

\section{Metode Pengumpulan Data}

Data primer Data yang di peroleh langsung dari responden melalui wawancara dengan menggunakan pedoman wawancara (kuesioner) dan Pengukuran Body Mass Index (BMI).

\begin{tabular}{|c|c|c|c|c|c|c|}
\hline & & \multicolumn{3}{|l|}{ Umur } & \multirow[b]{2}{*}{ Total } & \multirow[b]{2}{*}{ P-value } \\
\hline & & $<=20-30$ tahun & 31-40 tahun & $>40$ tahun & & \\
\hline \multirow[t]{4}{*}{ Infertil } & \multirow[t]{2}{*}{ Infertil } & 8 & 8 & 1 & 17 & \multirow{6}{*}{0,162} \\
\hline & & $11.4 \%$ & $11.4 \%$ & $1.4 \%$ & $24.3 \%$ & \\
\hline & \multirow[t]{2}{*}{ Tidak Infertil } & 16 & 23 & 14 & 53 & \\
\hline & & $22.9 \%$ & $32.9 \%$ & $20.0 \%$ & $75.7 \%$ & \\
\hline \multirow{2}{*}{\multicolumn{2}{|c|}{ Total }} & 24 & 31 & 15 & 70 & \\
\hline & & $34.3 \%$ & $44.3 \%$ & $21.4 \%$ & $100.0 \%$ & \\
\hline
\end{tabular}
Data sekunder adalah data yang diperoleh dari RSU. Sembiring dan Instansi terkait lainnya. Data sekunder digunakan dalam penelitian ini untuk mendukung data-data primer sehingga pembahasan penelitian dapat lebih luas dilakukan.

\section{HASIL PENELITIAN}

Tabel 1. Hubungan Umur dengan kejadian Infertil

Hasil penelitian pada tabel 1 menunjukkan bahwa responden dengan klasifikasi infertil mayoritas berusia <20 sampai dengan 40 tahun, sedangkan pada responden dengan klasifikasi tidak infertil mayoritas berusia 31-40 tahun.Hasil analisis statistik menunjukkan nilai p-value 0,162 , artinya tidak ada hubungan secara statistik antara umur dengan kejadian infertil. Hasil penelitian pada tabel 2 menunjukkan bahwa mayoritas responden dengan klasifikasi infertil memiliki masa kerja $>6$ tahun, sedangkan pada responden dengan klasifikasi tidak infertil, mayoritas responden memiliki masa kerja 4->6 tahun. Hasil analisis statistik menunjukkan bahwa nilai p-value 0,003, sehingga dapat disimpulkan bahwa terdapat hubungan antara masa kerja dengan kejadian infertil 
Flora Panjaitan R, Manurung E: Analisis Faktor Resiko Kejadian Infertilitas Pada Perawat di RSU Sembiring

Tabel 2. Hubungan Masa Kerja dengan Kejadian Infertil

\begin{tabular}{|c|c|c|c|c|c|c|}
\hline & & \multicolumn{3}{|c|}{ Masa Kerja } & \multirow[b]{2}{*}{ Total } & \multirow[b]{2}{*}{ P-value } \\
\hline & & 1-3 tahun & 4-6 tahun & $>6$ tahun & & \\
\hline \multirow[t]{4}{*}{ Infertil } & \multirow[t]{2}{*}{ Infertil } & 2 & 1 & 14 & 17 & \multirow{6}{*}{0,003} \\
\hline & & $2.9 \%$ & $1.4 \%$ & $20.0 \%$ & $24.3 \%$ & \\
\hline & \multirow[t]{2}{*}{ Tidak Infertil } & 15 & 19 & 19 & 53 & \\
\hline & & $21.4 \%$ & $27.1 \%$ & $27.1 \%$ & $75.7 \%$ & \\
\hline \multirow{2}{*}{\multicolumn{2}{|c|}{ Total }} & 17 & 20 & 33 & 70 & \\
\hline & & $24.3 \%$ & $28.6 \%$ & $47.1 \%$ & $100.0 \%$ & \\
\hline
\end{tabular}

Tabel 3. Hubungan status gizi responden dengan kejadian Infertil

\begin{tabular}{|c|c|c|c|c|c|c|}
\hline & & \multicolumn{3}{|c|}{ Status Gizi } & \multirow[b]{2}{*}{ Total } & \multirow[b]{2}{*}{ p-value } \\
\hline & & Kurang & Normal & Lebih & & \\
\hline \multirow[t]{4}{*}{ Infertil } & \multirow[t]{2}{*}{ Infertil } & 8 & 1 & 8 & 17 & \multirow{6}{*}{0,001} \\
\hline & & $11.4 \%$ & $1.4 \%$ & $11.4 \%$ & $24.3 \%$ & \\
\hline & \multirow[t]{2}{*}{ Tidak Infertil } & 18 & 28 & 7 & 53 & \\
\hline & & $25.7 \%$ & $40.0 \%$ & $10.0 \%$ & $75.7 \%$ & \\
\hline \multirow[t]{2}{*}{ Total } & & 26 & 29 & 15 & 70 & \\
\hline & & $37.1 \%$ & $41.4 \%$ & $21.4 \%$ & $100.0 \%$ & \\
\hline
\end{tabular}

Hasil penelitian pada tabel 3 menunjukkan bahwa mayoritas responden dengan klasifikasi infertil memiliki status gizi kurang dan statusi gizi lebih, sedangkan pada responden dengan klasifikasi tidak infertil, mayoritas responden memiliki status gizi normal. Hasil analisis statistik menunjukkan bahwa nilai p-value 0,001, sehingga dapat disimpulkan bahwa terdapat hubungan antara status gizi dengan kejadian infertil.

Tabel 4.Faktor yang paling berpengaruh terhadap kejadian Infertil pada Perawat di RSU. Sembiring

\begin{tabular}{|c|c|c|c|c|c|c|c|c|c|}
\hline & & \multirow[b]{2}{*}{ B } & \multirow[b]{2}{*}{ S.E. } & \multirow[b]{2}{*}{ Wald } & \multirow[b]{2}{*}{ df } & \multirow[b]{2}{*}{ Sig. } & \multirow[b]{2}{*}{$\operatorname{Exp}(B)$} & \multicolumn{2}{|c|}{$\begin{array}{ll}95,0 \% & \text { C.I.for } \\
\operatorname{EXP(B)} & \end{array}$} \\
\hline & & & & & & & & Lower & Upper \\
\hline \multirow[t]{4}{*}{ Step $1^{\mathrm{a}}$} & $\begin{array}{l}\text { MasaKer } \\
\text { ja }\end{array}$ & -1.488 & .541 & 7.562 & 1 & .006 & .226 & .078 & .652 \\
\hline & $\begin{array}{l}\text { StatusGiz } \\
\mathrm{i}\end{array}$ & -1.048 & .480 & 4.774 & 1 & .029 & .351 & .137 & .898 \\
\hline & Infeksi & 2.360 & .800 & 8.712 & 1 & .003 & 10.594 & 2.210 & 50.783 \\
\hline & Constant & 3.250 & 1.710 & 3.611 & 1 & .057 & 25.789 & & \\
\hline
\end{tabular}

Berdasarkan hasil analisis di atas diketahui bahwa terdapat 3 variabel yang berhubungan dengan kejadian Infertilitas pada perawat di RSU. Sembiring yaitu Masa Kerja dengan nilai sig.0,006, Status Gizi dengan nilai sig.0,029 dan Infeksi pada Organ Reproduksi dengan nilai sig. 0,003.Berdasarkan nilai $\operatorname{Exp}(\mathrm{B})$ diketahui bahwa variabel yang paling berpengaruh terhadap kejadian infertil pada Perawat di RSU. Sembiring yaitu Infeksi Organ Reproduksi 
Flora Panjaitan R, Manurung E: Analisis Faktor Resiko Kejadian Infertilitas Pada Perawat di RSU Sembiring

dengan nilai 10,594, sehingga dapat diasumsikan bahwa Perawat yang mengalami Infeksi pada Organ Reproduksi 10,594 kali lebih berpeluang untuk mengalami kejadian Infertilitas.

\section{PEMBAHASAN}

Investigasi infertilitas biasanya segera dilakukan ketika pasangan datang untuk konsultasi pertama kali. Jika pasangan telah melakukan usaha untuk memperoleh kehamilan selama kurang dari 1 tahun, maka pengajuan beberapa pertanyaan guna memastikan permasalahan utama sangatlah bermanfaat, pertanyaan yang dapat diajukan antara lain mengenai ketidakteraturan siklus menstruasi, riwayat adanya bedah pelvis, atau orkidopeksi yang tidak bisa dihindari. Jika riwayat medis pasangan hasilnya normal, maka pasien harus diberi penjelasan mengenai harapan peluang kehamilan kumulatif selama satu periode waktu dan investigasi sebaiknya ditunda sampai pasangan telah mencobanya selama periode satu tahun. Penelitian mengenai fertilitas pada populasi Hutterite menunjukan kesuburan menurun sesuai dengan pertambahan umur. Dimana angka fertilitas rendah 2,4\%,11\% wanita tidak melahirkan anak setelah umur 34, 33\% infertil pada umur 40, dan $87 \%$ infertil pada umur 45. Dengan meningkatnya usia, semakin sulit pula untuk mendapatkan anak. Usia 20-24 tahun fertilitas wanita mencapai $100 \%$, Usia 30-34 tahun, fertilitas wanita $85 \%$. Usia 3539 tahun fertilitas wanita tinggal $60 \%$. Pada usia 40-44 tahun fertilitas wanita tinggal $25 \%$. Penyebab seorang wanita dan pria menjadi infertil juga dapat disebabkan oleh faktor risiko yang meningkat yaitu gaya hidup yang tidak terkontrol yang diterapkan sejak usia remaja. Faktor-faktor tersebut adalah usia, kebiasaan merokok, mengkonsumsi alkohol, stress, diet yang buruk, olah raga berat, mengalami overweight ataupun underweight, penyakit menular seksual, keadaan lingkungan yang buruk (polusi udara dan air), juga masalah kesehatan yang berhubungan dengan perubahan hormon

\section{KESIMPULAN}

Berdasarkan nilai $\operatorname{Exp}(\mathrm{B})$ pada hasil annalisis multivariat diketahui bahwa variabel yang paling berpengaruh terhadap kejadian infertil pada Perawat di RSU. Sembiring yaitu Infeksi Organ Reproduksi dengan nilai 10,594, sehingga dapat diasumsikan bahwa Perawat yang mengalami Infeksi pada Organ Reproduksi 10,594 kali lebih berpeluang untuk mengalami kejadian Infertilitas.

\section{DAFTAR PUSTAKA}

WHO. glossary of ART terminology. Fertil Steril [Internet]. 2009;92(5):1520-4. Available from: http://dx.doi.org/10.1016/j.fertnstert. 2009.09.009

WHO. Global prevalence of infertility, infecundity and childlessness [Internet]. [cited 2018 Mar 21]. Available from: http://www.who.int/reproductiveheal th/topics/infertility/burden/en/

Syafrudin, Hamidah. Kebidanan Komunitas. Ester M, Wahyuningsih E, editors. Jakarta: EGC; 2009. $41 \mathrm{p}$.

HIFERI, PERFITRI, IAUI, POGI. Konsensus Penanganan Infertilitas. Konsensus Penanganan Infertilitas. 2013. 22 p.

Ambarwati P. Asuhan Kebidanan Komunitas. Yogyakarta: Nuha Medika; 2009.

Simanjutak Ls. Hubungan Obesitas Dengan Infertilitas Pada Ibu Pasangan Usia Subur Di Desa Wonosari Tanjung Morawa Tahun 2014. 2014.

Manuaba, Chandranita IA. Memahami Kesehatan Reproduksi Wanita. 2nd ed. Jakarta: EGC; 2009.

Speroff L, Fritz MA. Clinical Gynecologic Endocrinology and Infertility. $8^{\text {th }}$ ed Philadelphia, PA USA : Lippincont williams \& Wilkin, 2011 : pp 749-857 
Flora Panjaitan R, Manurung E: Analisis Faktor Resiko Kejadian Infertilitas Pada Perawat di RSU Sembiring

Dechanet C , Anahory T , Mathieu Daude J C , Quantin, X., Reyftmann L, Hamamah S , Hedon B , Dechaud, H. Effects of cigarette smoking on reproduction. Human Reproduction Update. 17.2010; (1): 76.

Set G.D, David B.S .Evaluation Of Female Infertility in Reproductive Endocrinology and Infertility,2010; Vol 16.

Al-Akour N, Khassawneh M, Zayed F, Khader Y. Characteristics of Woman Visiting an infertility clinic and their Interest in preimplantation Sex Selection in the North of Jordan. ECOG.2012; Vol 165,pp271-274.

Hestiantoro A.Infertilitas dalam : Anwar M,Baziad A,Prabowo RP, editor. Ilmu kandungan edisi Ketiga : Jakarta : PT Bina Pustaka Sarwono Prawirohardjo; 2011.hlmn 425-35

Robert L B. Female Infertility; Reproductive Endocrinology 7th Edition 2010.

\begin{tabular}{|l|l|l|l|}
\hline Accepted Date & Revised Date & Decided Date & Accepted to Publish \\
\hline 04 September 2020 & 10 September 2020 & 30 Oktober 2020 & Ya \\
\hline
\end{tabular}

